Journal of Urban and Regional Analysis, vol. VII, 2, 2015, p. 193 - 207

\title{
STEPS IN UNDERSTANDING THE ROLE OF INSTABILITY UPON URBAN TERITORRIAL SYSTEMS
}

\author{
Andrei SCHVAB, Igor SîRODOEV, Mirela PARASCHIV, Natașa VĂIDIANU \\ University of Bucharest, Interdisciplinary Centre for Advanced \\ Research on Territorial Dynamics
}

\begin{abstract}
Instability is an omnipresent process that creates the conditions for adaptation and change. A territorial system cannot develop without instability. A high degree of system instability points out an acute structural and functional disorder. The present study proposes a method to measure system instability through economic structural and functional changes inside urban territorial systems. The analysis is done by quantifying the changes and transfers in internal economic hierarchies. System instability shows the role that the system plays in its environment and consequently the measures that can be taken to amplify or hinder (depending on the desired outcome) that role. The conceptual framework captures the adaptive processes associated with system instability and both structural and functional changes are evidenced. The non-linear processes were analysed for the urban territorial system of Baia Mare (Romania) underlining their role in the city's adaptation to the changing of its environment. The proposed method starts from the assumption that internal systemic hierarchy is a very stable parameter of state. If the system is unstable, significant changes of the internal hierarchy will happen, and this will be reflected in a strong structural and functional shift. Measuring system instability helps better understanding the impact that change and adaptation have over the territorial system and its environment. Understanding these processes may offer policy makers the evidence they need to take actions in a conscious manner.
\end{abstract}

Key Words: systemic instability, self-organisation, urban territorial system, non-linearity, Baia Mare.

\section{Introduction}

Systemic instability relates to the dynamic interaction of the system variables that are under the influence of an unequal cause-effect relation that results into feedbacks and amplifications that change the structure and behaviour of the system. Such systems are defined as non-linear systems (Kiel 1991) that, under the impact of instability, continue to exist in a new form of equilibrium and a superior state of organization or, on the contrary, they may face chaos and a falling state of organization. But chaos generally represents only a stage in the entire existence of a system while instability transforms it after that into a new system with a different structure and functionalities grounded on its former identity and functions.

Non-linear processes represent the main drivers of territorial systems' dynamics and their analysis faces problems related to predictability, reproducibility, testability, and explainability. All these analysis prerequisites have one feature in common - instability, which is seen as the source of complexity, self-organization, and pattern formation (Langer 1980). In this way, measuring instability can represent a starting point for assessing a territorial system's complexity, self-organization, or determination of a specific pattern (system's identity). The evaluation of specific processes in non-linear territorial systems in relation to systemic instability should be done by rather more qualitative approaches than by 'pure' quantitative ones dedicated to classical technical and exact systems (Schmidt 2011, Hellesland 2012, Chesi 2015). 
In order to reveal such structural changes and non-linear processes inside a territorial system, a specific theoretical framework is also needed to create the necessary conceptualizations. In this sense, the theory of dissipative structures (Prigogine and Stengers 1984, Prigogine 1997) and the theory of complexity are best suited to conceptualize such types of phenomena (Allen 1982, Arthur et al. 1997, Krugman 1997, Ciliers 1998, Martin and Sunley 2006).

The theory of dissipative structures is currently part of the complexity theory while dissipative systems evolved to the complex adaptive systems that enter reconfiguration and restructuring processes as effect of the instability of systemic fluxes and relations. Dissipative structures (Prigogine and Stengers 1984, Prigogine 1997) represent open systems that exist based on the import and export of energy within the external environment (lanoş et al. 2011). So that, the system requires the entropy that is dissipated or exported back to the external environment in order to maintain its structure and functions. Dissipative structures have a strong dynamics built on vulnerability and non-linear (unstable) relations among the system components, resulting in minor changes with major impact within the system (Prigogine and Stengers 1984, Prigogine 1997).

The complexity theory relates also to the non-linear dynamics of the system's components. So that the system dynamics determined by instability faces different points of equilibrium, nonpredictability, inefficiency, asymmetry, lock-in situations and path dependence (Arthur et al. 1997). But the system dynamics is difficult to predict on long term as complexity involves the emergence of order as a result of auto-organization. These emergence and auto-organization processes conduct to (inconstant) resilience and adaptation along the dynamics of the system (Martin and Sunley 2010, Walker and Cooper 2011).

Urban territorial systems function closely to socio-ecological systems that are founded also on an identity of their own (Cumming and Collier 2005) and their internal structure relates to the external environment while they are also vulnerable to disturbances so that they require increased adaptability and resilience (Gallopin 2006, Young et al. 2006, Zurlini et al. 2006, Stokols et al. 2013, Garmestani 2014, Sikula et al. 2015, Văidianu et al. 2015).

The identity or profile of territorial systems should be stable over long periods of time. If this profile is unstable, system instability leads to the emergence of new structures, functions and hierarchies that allow the existence of the territorial system. This happens through the action of another domain of attractors as influenced by the system parameters that change the attraction area to another one characterized by a different type of dynamics.

Systemic instability may be analysed through demographic, economic, social, cultural and spatial variables taking into account their different feedback time. Also, territorial systems may respond differently in terms of rapidity although under the impact of similar intensity of instability processes. Generally, territorial continuities and discontinuities (lanos and Heller 2006, Humeau et al. 2010, Finka and Kluvánková 2015) generate more reduced or higher instability impulses among the systems. In the same time, shocks are strongly received or more attenuated while territorial systems process shocks slowly in comparison to a faster handling of others while other systems remain inert to them. Systems' resilience constitutes the main agent of these diverse situations of instability impact. System resilience is defined through the quantity of absorbed shocks before a structural change takes place or as the required time for the system: 1. to recover to its initial state of equilibrium; or 2. to reorganize in search of another point of equilibrium based on its former structure and functionality (Gunderson 2000, Folke 2006, Pike et al. 2010, Filatova and Polhill 2012).

System instability evidences changes in the intensity and direction of flows that run through the territorial system (Zhao 2012, Morandi et al. 2014). The purpose of the study is to present a possible way to determine system instability by revealing the structural and functional changes 
generated by economic processes that act inside an urban territorial system (the city of Baia Mare, Romania) in a certain time frame (between 2001 and 2010). The analysis focuses on the factors and processes of radical change in identity and economic structure for the urban territorial system while systemic instability had a crucial role in assuring its adaptive capacity. Within this systemic approach (lanoș 2000, Flood 2010) of urban territories, a second purpose is to highlight the non-linear processes that come along with this structural change of a local or regional economy: emergence, self-organization and path-dependency (Kiel 1991, Gunderson 2000, Folke 2006, Page 2006, Martin and Sunley 2010, Pike et al. 2010).

\section{Methodology}

Study Area. Baia Mare is a medium size city in the urban hierarchy of Romanian cities, being the county capital of Maramureș. Baia Mare is the third largest city in the North-West development region, after Cluj-Napoca and Oradea (Fig. 1). Until the mid of the 90s, Baia Mare was an important industrial city specialized in extracting non-ferrous ores (gold, silver, copper, zinc and lead) and in preparing them as secondary resources for other industrial uses. Machine building and chemical industry were the other activities that shaped the economic profile of the city. The city had a great influence over the regional economy as it attracted workers from a large hinterland making thus Baia Mare act as a central place. This urban territorial system provided strategic resources for the national economy and it provided working places directly and indirectly for much of the counties inhabitants. Fallowing the socio-economic and political changes from 1989 (Bănică and Muntele 2015), Baia Mare started to lose its previous role in the national economy due to a radical shift in the international economical patterns and trade and production that Romania had to undergo. The urban territorial system of Baia Mare went through a radical change of identity. The inhabitants of Baia Mare and from the other surrounding areas depended on the ability of the urban territorial system to adapt to the new economic patterns and to create new economic structures and relations. A new identity was thus created.

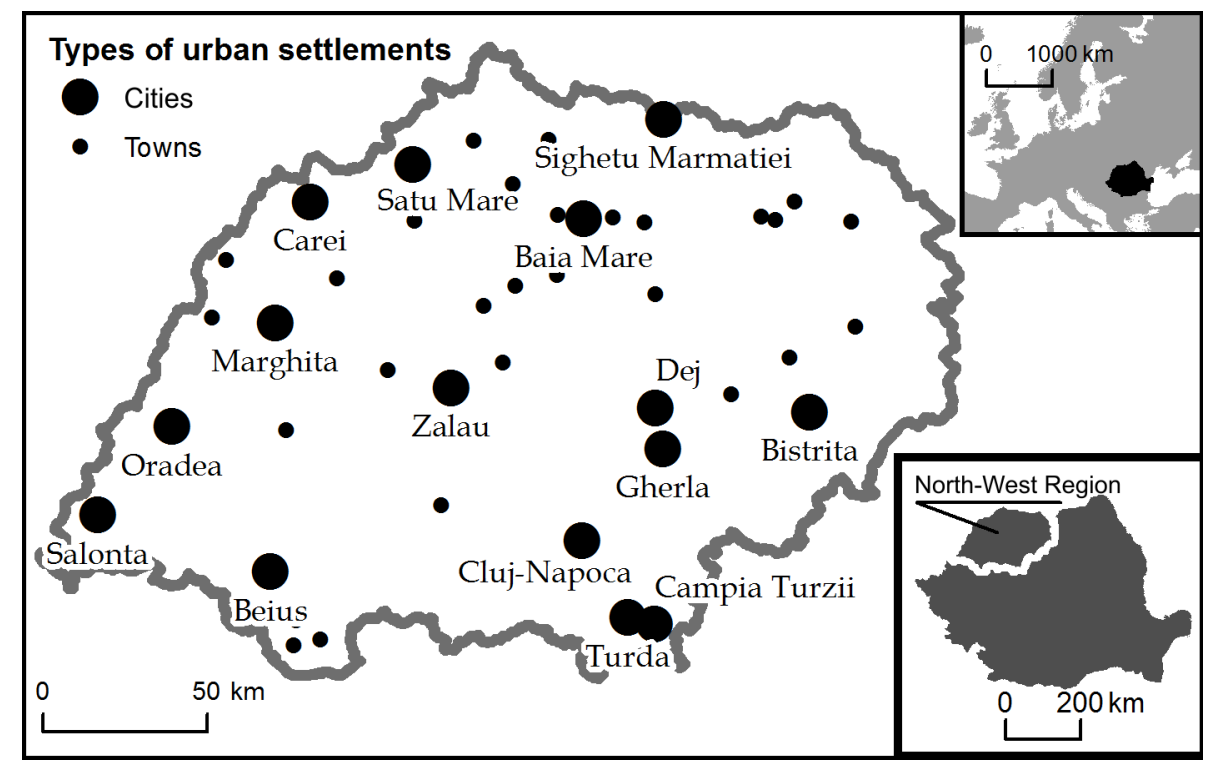

Fig. 1 - Baia Mare and the regional urban system 
Applied systemic instability assessment. The objectives of this research were met by using the simple method of the single criteria classification. In this sense, a ranking of the first fifteen economic activities that generated the highest turnover was made for every year in the established 2001-2010 time range. After the ranking for each year, an analysis of the inputs and outputs (how many pairs of economic activities left/entered the hierarchy created by the top 15 turnover producers) was undergone in order to reveal the internal dynamics of Baia Mare as representing the urban territorial system case study. In this logic, all NACE (nomenclature of economic activities) activities that make up the economy of Baia Mare city were centralised for the 2001-2010 reference period. Then, the classification of the top 15 NACE turnover producers for each year was analysed in order to highlight the changes that took place inside the territorial system. The next step of the analysis included the centralisation of these changes, focusing on the pairs of exits and entrances in the hierarchy, in order to search the different patterns created. So that, patterns of stable and unstable economic activities were revealed and systemic instability was conceptualized as marker for the presence of complex territorial processes (Kiel 1991, Manson and O'Sullivan 2006, Martin 2010). The analysis was completed by a short view on three significant industrial regions in Europe, underlining the different directions of addressing systemic instability inside urban systems and good practices for future development support.

\section{Results}

On the average, the first fifteen NACE codes inside the analysed urban territorial system represented $4 \%-5 \%$ of the total NACE codes that existed in Baia Mare's economy. These top 15 economic activities generated from $45 \%$ to $55 \%$ of the total turnover produced by Baia Mare's economy.

Taking into account the economic activities that generated the highest turnover in 2001 (Table 1 ), the economic profile of the 3rd biggest city in the North-West development region was defined by activities that belonged to commerce and the trade sector. Mining, manufacturing of technological equipment, freight transport, meat processing, constructions, textile industry and metallurgic industry completed this economic profile, specific to a city that already underwent major changes from 1989 until 2000. The closing of mines starting from 1997 and the major dismissal of employees represented the processes with a major impact on the local and regional economy centred on the urban territorial system of Baia Mare.

In 2002, the economic structure was mostly stable apart from the arrival of two new-comers: NACE 3109 - Manufacture of furniture, and NACE 3103 - Manufacture of mattresses. A significant change that happened in 2002 was the rise of mining activities on the first position of the economic hierarchy as representing the biggest turnover generator inside the urban territorial system of Baia Mare. In 2003, the first three positions remained unchanged (mining, wholesale of food, beverage and tobacco and retail sale of food, beverage and tobacco). The newcomer manufacturer of mattresses climbed up to the fifth position, after an increase of its turnover with 15 million Euros in one year.

The year of 2004 confirmed the ascension of the two companies under the NACE code 3103 (manufacture of mattresses). This economic activity managed to double its turnover in 2004 taking the second position in the hierarchy of the largest fifteen producers of turnover. After that, in 2005, the manufactures of mattresses overthrew the emblematic economic activity of the entire region - mining - that for many years represented the biggest producer of turnover. So that, mining fell on the second position being followed by other economic activities such as: the wholesale and retail sale of food; beverage and tobacco. 
Changes in the hierarchy of the Top 15 economic activities in Baia Mare, considering the turnover between 2001 and 2010

\begin{tabular}{|c|c|c|c|c|c|c|}
\hline & $\begin{array}{l}\text { NACE } \\
\text { Code }\end{array}$ & $\begin{array}{l}\text { Hierarchy of Top } 15 \\
\text { economic activities } \\
\text { (in 2001) }\end{array}$ & $\begin{array}{l}\text { Turnover } \\
\text { in million } \\
\text { Euros } \\
(2001)\end{array}$ & $\begin{array}{l}\text { Turnover } \\
\text { in million } \\
\text { Euros } \\
(\mathbf{2 0 1 0 )}\end{array}$ & $\begin{array}{c}\text { Place } \\
\text { in } \\
2001 \\
\text { (out of } \\
333 \text { ) }\end{array}$ & $\begin{array}{c}\text { Place } \\
\text { in } \\
2010 \\
\text { (out of } \\
402)\end{array}$ \\
\hline 1 & 4711 & $\begin{array}{l}\text { Retail sale (food, beverage and } \\
\text { tobacco) }\end{array}$ & 34 & 42 & 1 & 5 \\
\hline 2 & 4639 & $\begin{array}{l}\text { Wholesale (en gross) of food, } \\
\text { beverage and tobacco }\end{array}$ & 27 & 28 & 2 & 9 \\
\hline 3 & 729 & Mining of nonferrous ores & 26 & 2.1 & 3 & 103 \\
\hline 4 & 8299 & $\begin{array}{l}\text { Other support activities for } \\
\text { enterprises }\end{array}$ & 23 & 5.6 & 4 & 47 \\
\hline 5 & 2822 & $\begin{array}{l}\text { Manufacturing of lifting and handling } \\
\text { equipment }\end{array}$ & 20 & 23 & 5 & 14 \\
\hline 6 & 4941 & Freight transport by road & 18 & 32 & 6 & 4 \\
\hline 7 & 1011 & Meat processing and preservation & 15 & 22 & 7 & 15 \\
\hline 8 & 4120 & $\begin{array}{l}\text { Construction of residential and non- } \\
\text { residential buildings }\end{array}$ & 15 & 116 & 8 & 1 \\
\hline 9 & 4719 & $\begin{array}{l}\text { Other retail sale in } \\
\text { non-specialized shops }\end{array}$ & 14 & 19 & 9 & 16 \\
\hline 10 & 1413 & $\begin{array}{l}\text { Manufacturing of other types of } \\
\text { clothes }\end{array}$ & 14 & 17 & 10 & 18 \\
\hline 11 & 4690 & $\begin{array}{l}\text { General unspecialized wholesale } \\
\text { (en gross) }\end{array}$ & 12 & 26 & 11 & 12 \\
\hline 12 & 4673 & $\begin{array}{l}\text { Wholesale of wood, construction } \\
\text { and sanitary materials }\end{array}$ & 9 & 35 & 12 & 6 \\
\hline 13 & 6619 & $\begin{array}{l}\text { Other activities auxiliary to financial } \\
\text { services, except insurance and } \\
\text { pension funding }\end{array}$ & 9 & 0.3 & 13 & 201 \\
\hline 14 & 2511 & $\begin{array}{l}\text { Manufacturing of metal structures } \\
\text { and parts of structures }\end{array}$ & 8 & 16 & 14 & 20 \\
\hline 15 & 2341 & $\begin{array}{l}\text { Manufacture of household ceramics } \\
\text { and ornamental articles }\end{array}$ & 8 & 4 & 15 & 71 \\
\hline 16 & 3109 & Furniture manufacturing & 7 & 83 & 19 & 2 \\
\hline 17 & 3103 & Mattresses manufacturing & 0.5 & 69 & 111 & 3 \\
\hline 18 & 4773 & $\begin{array}{l}\text { Retail sale of pharmaceutical } \\
\text { products }\end{array}$ & 4 & 31 & 28 & 7 \\
\hline 19 & 1610 & Sawmilling of wood and planing & 7 & 29 & 17 & 8 \\
\hline 20 & 1013 & Production of meat & 3 & 27 & 31 & 10 \\
\hline 21 & 4520 & Automotive repair and service & 3 & 26 & 36 & 11 \\
\hline 22 & 4531 & Whole sale of motor parts & 5 & 24 & 24 & 13 \\
\hline
\end{tabular}

Source: calculated data based upon listafirme.ro

The first two positions in the economic rank remained the same in 2006. The considerable change of this year's hierarchy was the strong increase of the constructions' turnover. Another new-comer of 2006 that was going to shape the rank in the coming years was represented by sawmilling and planing of wood (NACE 1610), taking the hierarchical place of support activities for enterprises (NACE 8299).

In 2007, constructions took over the first place of the rank as the biggest turnover generator among the economic activities of Baia Mare. But the most important change that happened in 2007 was the almost total disappearance of the mining activity that suffered a sudden drop in 
its annual turnover, from 71 million Euros to 12 million Euros, and then to 4.6 million Euros in 2010. So that, the main economic activity that supported the entire regional economy collapsed. The first three positions of the economic hierarchy now belonged to activities such as constructions, manufacture of mattresses and freight transport. These three economic activities generated together $15 \%$ of the total turnover of Baia Mare. In the same time, the turnover generated by the first 15 economic activities dropped from $52 \%$ to $44 \%$, as significance in the total economy of Baia Mare, but revealing a diversification of the other economic activities present inside the urban territorial system. Also, the economic hierarchy of the activities with the highest turnover showed a temporary exit of the manufacturers of lifting and handling equipment. Seven out of the fifteen activities included in the rank belonged to the commerce and trade domain.

2008 represents the year when the international economic and financial recession started, having an important impact also on the urban territorial system of Baia Mare, although its effect registered slightly later, starting with 2009 . But, until then, in 2008, the total volume of the city's turnover reached its maximum, in relation to the analysed time span (2001-2010). So that, the urban territorial system of Baia Mare produced in 2008 a total turnover of 1.6 billion Euros while its top 15 economic activities covered 707 million Euros of it. In the same time, the first two positions of the economic rank remained unchanged, being occupied by the domains of constructions and the manufacture of mattresses. In terms of dynamics, the economic hierarchy of Baia Mare was characterised by a maximum of two pairs of exits and entrances for the majority of the years from 2001 until 2008

But, this relative stability of the urban territorial system was strongly challenged in 2009 while the effects of the economic recession were fully received by the economy of Baia Mare. So that, the total turnover of the city lost 300 million Euros in only one year, registering a relative drop of $18.1 \%$. This general economic decrease was also observable in the hierarchy of the top 15 turnover producers, the loss being proportional to that of the total turnover of Baia Mare there was registered an economic contraction of $17.8 \%$, with a drop from 707 million Euros in 2008 to 581 million Euros in 2009.

Another effect of the economic crisis was the increase of economic instability inside the urban territorial system which was also reflected in the hierarchy of the top 15 turnover producers of Baia Mare. The economy dynamics based on this rank, registered a number of exit/entrance pairs that rose from 1-2 (the average until 2009) to four pairs. The strong change induced by the economic recession lead to several hierarchical shifts so that the economic activities that manufactured goods re-entered the 15 top turnover producers - the production of meat (NACE 1011), the preparation of meat (NACE 1013), the sawmilling of wood (NACE 1610) and the retail of pharmaceutical products (exception) took the place of automotive retail (NACE 4511), automotive exchange parts retail (NACE 4531), constructions of roads and metallurgic manufacturing (NACE 2511).

Traditionally, the constructions domain was considered one of the most vulnerable economic activities during economic recessions, but in the case of Baia Mare it registered a contraction of only $8 \%$, managing to stay in front of the hierarchy of the top 15 activities as the biggest turnover producer in the $3^{\text {rd }}$ largest city of North-West development region.

In 2010, the total turnover of Baia Mare increased with $2 \%$ from the previous year, while the increase of turnover for the top 15 economic activities was of almost $10 \%$. It can thus be observed that the large economic activities recovered faster than the entire economic environment of the urban territorial system. Also the economic dynamics constituted of the exits/entrances in the top 15 rank returned to normal values for the analysed urban territorial system. The end of 2010 found on the first four positions of the most important economic activities of Baia Mare: the constructions, the manufacturing of furniture, the manufacturing of 
mattresses and the freight transport by road. Also, five out of the total of fifteen economic activities belong to the commerce and trade domain.

Another important aspect of the urban territorial system economy is represented by the transition from its 2001 economic structure to the one of 2010. Seven economic activities from 2001 were absent from the rank of the largest 15 producers of turnover in 2010 . These activities are: 0729 - Mining; 1413 - Textile industry; 2341 - Manufacture of ceramic for household and ornamental articles; 2511 - Manufacture of metal structures and parts of structures; 4719 Retail sale in unspecialised shops; 6619 - Other activities auxiliary to financial services, except insurance and pension funding; and 8299 - Other support activities for enterprises.

At the end of 2010, the following economic activities are new compared to the top 15 hierarchy of 2001: 1013 - Production of meat and poultry meat products (enters the rank in 2009); 1610 - Sawmilling of wood (enters in 2006); 3103 - Manufacturing of mattresses (enters in 2002); 3109 - Manufacturing of furniture (enters in 2002); 4520 - Service of automobiles (enters in 2007); 4531 - Wholesale trade of motor vehicle parts and accessories (enters in 2004); 4773 Retail sale of pharmaceutical products (enters in 2009). If during the 2001-2010 period four manufacturing economic activities dropped out of the top 15, their places were taken by other four manufacturing economic activities in 2010.

Also of a special importance are the economic activities that were present in the top 15 ranking in 2001, then absented for a certain number of years in order to reappear in 2010 . These economic activities are 1011 -Processing of meat, and 2822 - Manufacturing of lifting and handling equipment. Their dynamics reveals that these economic activities have the capacity to come back strongly after the shocks they received due to different disturbances inside or upon the urban territorial system.

\section{Discussion}

The main findings of the analysis based on the economy dynamics of the urban territorial system of Baia Mare show that systemic instability generates opportunities for innovation, adaptation and development (Folke 2006).

The year of 2007 represented a turning point in the evolution of the economic profile of the urban territorial system of Baia Mare. This year revealed the manifestation of several non-linear processes like emergence understood as the appearance of a new economic structure with new economic leaders, while emblematic activities were pushed to the limit of extinction.

The process of self-organization started when the backbone of the regional economy disappeared almost entirely, but the urban territorial system resisted to collapse. The urban territorial system continued to exist, but under a different economic structure and functionality. Actually, the urban territorial system captured the effects of this traditional economic structure disappearance with little disturbance being produced, if we take into consideration only the volume of the total turnover and not the associated social effects. In fact, the volume of the total turnover of Baia Mare increased both in 2007 and in 2008. Afterwards, the decline of the general turnover of the urban territorial system was attributed to the turbulences created by the world economic crisis that manifested as instability and source of chaos (Choi and Douady 2012).

Over the 10 years that were analysed, few economic activities managed to enter the firstly established hierarchy of the top 15 turnover producers - there were only 26 entrances in total for the 2001-2010 period. Also, very few newcomers succeeded to maintain a constant presence in the top 15 ranking after their entrance. The specific of Baia Mare economy's dynamics constitutes the evidence that the stability of the hierarchy is high despite of the 
observed changes. These facts point out that the economic activities of the urban territorial system were strongly tied up to decisions made in the past and this constitutes one of the major causes that stopped them from having sudden jumps in the turnover volume, as a general rule.

The dynamics of the exits and entrances in the hierarchy of the top 15 turnover generators constructs the synthetic image of the structural change of the urban territorial system (Table 2). So that, the evolution of the economic profile of Baia Mare registers different situations of stability and instability, together with some sudden or random changes that took part and generated the transition from the 2000 economic profile to the specific one of 2010.

Taking into consideration the total turnover produced by the top 15 economic activities, this domain of attractors seems to be stable even though the changes that happened were massive. Between 2001 and 2010, six economic activities never left the top 15 hierarchy (Table 2):

- $\quad 4120$ - Construction of residential and non-residential buildings;

- 4639 - Wholesale (en gross) of food, beverage and tobacco;

- $\quad 4673$ - Wholesale of wood, construction and sanitary materials;

- $\quad 4690$ - General unspecialized wholesale (en gross);

- $\quad 4711$ - Retail sale (food, beverage and tobacco);

- 4941 - Freight transport by road.

As easily noticed, four out of six economic activities belong to the trade domain while any economic activity that belonged to the manufacturing sector had the necessary capacity and critical mass to hold its position without interruption in the top 15 hierarchy for the 2001-2010 period.

The group of economic activities with a presence of $90 \%$ among the major economy actors of the urban territorial system during the analysed time frame is made out of the manufacturers of mattresses (3103) and furniture (3109) and the retail sale in unspecialised shops (4719). The manufacturers of furniture and mattresses entered the top 15 economic activities of the city in 2002 and never left the hierarchy until 2010. Also, these activities represent the only newcomers that managed to improve their position and climb to the top 15 . If the manufacturers of furniture have a strong tradition in the region, the manufacturers of mattresses constitute a totally new activity with impact at this territorial scale.

At the end of 2010, the manufacturers of furniture and the manufacturers of mattresses represented the two economic activities that were producing the second and the third largest turnover in Baia Mare. Innovation and investment assured the economic performance and competitiveness of these activities while economic crisis related changes produced the instability of the economic environment (Choromides 2015, Nunes and Lopes 2015). Their example with the consolidation of their high position after managing to enter the top 15 economic activities of the urban territorial system depicts the classical example of breaking from the path-dependence (lanos 2000), but, as showed earlier, these represent the only two cases. Considering this fact, it can be summarised that the forces inside the hierarchy of turnover producers are very strong and conservative, allowing a very difficult process of position consolidation for the newcomers on the economy stage of the urban territorial system. 
Synthesis of the dynamics of economic activities that entered the hierarchy of the top 15 turnover producers in Baia Mare (2001-2010)

\begin{tabular}{|c|c|c|c|c|c|c|c|c|c|c|c|}
\hline $\begin{array}{l}\text { NACE } \\
\text { code }\end{array}$ & 옹 & 응 & 今. & No & N & 옹 & 옹 & ్ㅗㅇ & 옹 & $\begin{array}{l}\text { N } \\
\text { Oे }\end{array}$ & $\begin{array}{l}\text { Frequency of } \\
\text { appearance in } \\
\text { top } 15(\%)\end{array}$ \\
\hline 729 & & & & & & & & & & & 60 \\
\hline 1011 & & & & & & & & & & & 40 \\
\hline 1013 & & & & & & & & & & & 20 \\
\hline 1413 & & & & & & & & & & & 50 \\
\hline 1610 & & & & & & & & & & & 40 \\
\hline 2341 & & & & & & & & & & & 10 \\
\hline 2511 & & & & & & & & & & & 80 \\
\hline 2822 & & & & & & & & & & & 70 \\
\hline 3103 & & & & & & & & & & & 90 \\
\hline 3109 & & & & & & & & & & & 90 \\
\hline 4120 & & & & & & & & & & & 100 \\
\hline 4211 & & & & & & & & & & & 20 \\
\hline 4322 & & & & & & & & & & & 20 \\
\hline 4511 & & & & & & & & & & & 30 \\
\hline 4520 & & & & & & & & & & & 40 \\
\hline 4531 & & & & & & & & & & & 60 \\
\hline 4639 & & & & & & & & & & & 100 \\
\hline 4673 & & & & & & & & & & & 100 \\
\hline 4690 & & & & & & & & & & & 100 \\
\hline 4711 & & & & & & & & & & & 100 \\
\hline 4719 & & & & & & & & & & & 90 \\
\hline 4773 & & & & & & & & & & & 20 \\
\hline 4941 & & & & & & & & & & & 100 \\
\hline 5630 & & & & & & & & & & & 10 \\
\hline 6619 & & & & & & & & & & & 10 \\
\hline 8299 & & & & & & & & & & & 50 \\
\hline \multicolumn{12}{|c|}{ present } \\
\hline Legend & \multicolumn{3}{|c|}{ absent } & & & & & & & & \\
\hline
\end{tabular}

Source: calculated data

Economic activities that have a presence of $50 \%$ or lower in the $2001-2010$ rank of the top turnover generators can be characterized by a lack of critical mass and an important inconsistency in keeping the position they formerly won. But, a special attention is required by the group of economic activities with a presence of only $10 \%$ or $20 \%$ in the hierarchy of the most influent economic actors. These activities can be defined as accidents of appearance in the top 15 rank, but they still have the necessary throb to make it as the most important generators of turnover although they lack the capacity to maintain a sufficient critical mass to keep their gained position. But, the economic activities with this kind of meteoric appearance can always perform a sudden jump in the hierarchy if the territorial conditions are suited (Braghină et al. 2011).

The economic profile of the city of Baia Mare changed radically taking into consideration the transformations of the turnover volume and structure. Seven out of the fifteen economic activities that were producing the largest turnover in 2001 dropped out of the top 15 rank in 2010. The emblematic and traditional economic activities for the economy of the entire region mining and metallurgic industry (gold-silver ores and other complex ores) - contracted their 
action reaching the limit of extinction. Their top places were taken by the furniture and mattresses manufacturers. Although the industry of furniture represents also a tradition for the region, the producing of mattresses constitutes a complementary activity which is exogenous for the region and it is characterised by high entropy (González de Molina and Toledo 2014), fact that may put the urban territorial system in a vulnerable state and impact it negatively. The sustainable development of the urban territorial system requires to presence of endogenous fluxes as they increase its capacity to adapt to systemic instability and, concretely, to the shocks produced on the free market. Also, the strong position held by trade activities in the economy of Baia Mare and their continuous development represent a strong point of concern considering that such activities drain out the financial capital of the urban territorial system.

Systemic instability generated both positive and negative feedbacks upon the urban territorial system. While the accumulation of positive feedbacks may also lead to instability and to a critical point where the system is unable to maintain its continuity, negative feedbacks determine the reduction of the volume, intensity and frequency of the causes that produces certain effects. In this way, the negative feedback of systemic instability employs a role of control or regulator upon the urban territorial system. As a concrete example for the city of Baia Mare, instability inside its economic system during the transition period resulted in increased unemployment rate. But the high number of unemployed people generated a significant search of jobs outside the country. While the unemployed population out-migrated, the number of the unemployed decreased inside the urban territorial system of Baia Mare.

Systemic instability allowed the urban territorial system of Baia Mare to adapt to different types of economic environment changes, although the costs of this adaptation were extremely high economically and, most of all, socially. But the chaos that the urban territorial system had to face during the reshaping of its economic structure triggered not only costs, but also some benefits, which accomplish a significant role in the manifestation of adaptive processes (Hinsch and Komdeur 2010). So that, as result of exogenous socio-economic factors, the territorial pressure and stress exerted over the physical urban environment reduced significantly once the mining and metallurgic industry were closed and land use transition produced as a nonlinear process in association with these economic changes having both social and environmental implications (Ohla et al. 2007, Lambin and Meyfroidt 2010, Șerban and Tălângă 2015). Another benefit related to the manifestation of systemic instability is constituted by the fact that the urban territorial system adapted successfully to the structural changes and it allowed the development process to restart.

Ruhr region (Germany), the Moravian-Silesian region (Czech Republic), and the Silesian region (Lower Silesian Voivodeship, and the Silesian Voivodeship in Upper Silesia, Poland) represent several examples of former industrial territories across Europe taken as case studies for assessing systemic instability and its role in defining new urban systems. These regions developed on a common functionality - heavy industry founded on coal mining - and entered a similar evolution path based on non-linear processes. Generally, all mentioned regions faced three types of shock and disruption that generated the strong diminishing of their initial industrial activity: 1. the shift of the international economic pattern activities from the heavy industry to the highly specialised industry and the growth of the tertiary sector; 2 . competition on global markets; and 3. the stop of governmental funding due to the European Union development regulations (Riley and Tkocz 1999, Kretschmann 2013). As a result, the industrial European regions of this type required adaptation measures and new directions of existence. Systemic instability generated significant changes in their structure and functionality but they proved a high degree of resilience and continued their economic activities achieving growth at a different level. But, there can be easily observed a gap between the West and the (former communist) East due to different development contexts (Blazyca et al. 2002, Adamovský and Holešinská 2012). 
So that, among these case studies, Ruhr area represents a model of recovery and positive impact of instability on all territorial components of the system through a tertiary-type economic restructuring and the implementation of a sustainable land management built on integrated governance (Wegener 2012, Chmielewska and Otto 2013, Kretschmann 2013, Reuschke et al. 2013). A comparison between the Moravian-Silesian region and the Silesian region, which are more similar in terms of evolution and dynamics, shows that the type of addressing instability severe restructuring for the first case; and cautious restructuring grounded on entrepreneurship and a special taxing system, in the second case - constitutes the main factor of achieving or not successful redevelopment (Adamovský and Holešinská 2012, Hajduga 2014). So that, the Moravian-Silesian region faced unsustainable growth and fragile resilience while the Silesian region followed a continuous gradual development-based transformation path even under the economic crisis impact (Riley and Tkocz 1999, Adamovský and Holešinská 2012, Kenc 2013, Popławski 2013, Hajduga 2014). But both urban systems - the Silesian region and the Moravia -Silesian region, currently functioning on different industrial activities - require the assuming of new changes and adaptation processes to sustain their development on long-term (Olszak and Ziemba 2011, Tödtling et al. 2011, Zuzańska Żyśko and Szajnowska Wysocka 2013, Hajduga 2014).

In relation to the urban territorial system of Baia Mare, the European case studies highlight the importance of regional development and multiple stakeholders' intervention grounded on a sustainable planning approach for supporting economic growth through complex activities in the context of a more globalised systemic instability.

For future research, systemic instability and its impact upon urban territorial systems may be addressed through analysing disturbance patterns and identifying sustainable directions for their management and the support of system's adaptation and resilience processes (Zurlini et al. 2006).

\section{Conclusions}

Systemic instability proved the complexity of the urban territorial system of Baia Mare. Under the impact of systemic instability and within the framework of resilience, the urban territorial system under analysis followed the second path, reorganizing itself until another point of equilibrium was achieved. As a synthesis of the situation, the ' 90 s economic system of Baia Mare, dominated by mining and metallurgic industry, faced the national economic change and transition from the planned economy to the market economy as a significant shock competitiveness on a free market represented the main triggering factor of systemic instability. Resulted structural and functional changes were major while mining industry collapsed and stopped its activity and the metallurgic industry considerably reduced its activity. The territorial framework of system instability stopped the economic system of Baia Mare to recover to its parameters before the shock. But the economy of the urban territorial system continued to function, and, after a certain time, efficiently, grounded on new parameters and another domain of economic attraction.

The emergence of a different economic leader inside the system economy produced the manifestation of the process of auto-organization that resulted in changes of the structure and economic profile of Baia Mare. Involving adaptation, the alternative point of economic system equilibrium was attained while this novel organisation of the urban territorial system was more resilient to the new instability manifestations than the former system structure and functionality.

Systemic instability created the necessary context for some businesses to grow and replace the economic activities that became obsolete and inefficient. In this way the urban territorial system reshaped its function and structure to fit the conditions of the existing environment. 
The shock induced by the extinction of emblematic economic activities was absorbed by the system and its influence on the level of the total turnover was small. Instead, the main disturbing factor was represented by a global system instability phenomenon (Young et al. 2006) - the economic recession - that led to a significant drop of the total turnover in only one year. All these changes registered inside the economy of the urban territorial system revealed the emergence of a new economic structure and profile, where trade and non-traditional economic activities lead a dominant position.

Complexity of urban territorial systems requires an integrated approach in addressing systemic instability in relation to all territorial components (including the social, environmental, resource and land use issues together with its economic aspects) founded on strategic planning (lanoş et al. 2009, Pincetla et al. 2012, Comino and Ferretti 2016) and anticipatory governance (Boyd et al. 2015) in order to employ the required comprehensive instruments of management and action.

\section{Acknowledgements}

This work was supported by a grant of the Romanian National Authority for Scientific Research and Innovation, CNCS - UEFISCDI, project number PN-II-RU-TE-2014-4-1481.

\section{References}

ADAMOVSKÝ J., HOLEŠINSKÁ L. (2012), Comparative analysis of chosen development aspects in selected central and Western European regions, Journal of Economics \& Management 10, 152-163.

ALLEN P. M. (1982), Evolution, Modelling, and Design in a Complex world, Environment and Planning B: Planning and Design 9 (1), 95-111.

ARTHUR W. B., DURLAUF S., LANE D. (1997), The Economy as an Evolving Complex System II, Addison-Wesley, Reading.

BĂNICĂ A., MUNTELE I. (2015), Urban vulnerability and resilience in post-communist Romania (comparative case studies of lași and Bacău cities and metropolitan areas), Carpathian Journal of Earth and Environmental Sciences 10 (4), 159-171.

BLAZYCA B., HEFFNER K., HELIŃSKA-HUGHES E. (2002), Poland - can regional policy meet the challenge of regional problems? European Urban and Regional Studies 9 (3), 263-276.

BOYD E., NYKVIST B., BORGSTROM S., STACEWICZ I. A. (2015), Anticipatory governance for social-ecological resilience, AMBIO 44 (Suppl. 1), S149-S161.

BRAGHINĂ C., PEPTENATU D., DRĂGHICl C., PINTILII R., SCHVAB A. (2011), Territorial management within the systems affected by mining. Case study the South-Western Development Region in Romania, Journal of Environmental Health Science Engineering 8 (4), 343-352.

CHESI G. (2015), Quantifying the unstable in linearized nonlinear systems, Automatica $60,210-218$.

CHMIELEWSKA M., OTTO M. (2013), The impact of revitalization on the evolution of urban space on former iron and steel works areas in Ruhr region (Germany), Environmental \& Socio-economic Studies 1 (1), 31-37.

CHOROMIDES C. (2015), An analysis of the economic determinants and the quality of the institutional framework as factors to attract foreign direct investment in South-Eastern Europe: the case of Greece, Journal of Urban and Regional Analysis 7 (1), 35-58.

CHOI Y., DOUADY R. (2012), Financial crisis dynamics: attempt to define a market instability indicator, Quantitative Finance 12 (9), 1351-1365. 
CILIERS P. (1998), Complexity and Postmodernism: understanding complex systems, Routledge, London.

COMINO E., FERRETTI V. (2016), Indicators-based spatial SWOT analysis: Supporting the strategic planning and management of complex territorial systems, Ecological Indicators 60, 1104-1117.

CUMMING G. S., COLLIER J. (2005), Change and identity in complex systems, Ecology and Society 10 (1), 29.

FILATOVA T., POLHILL G. (2012), Shocks in coupled socio-ecological systems: what are they and how can we model them? Proceedings International Environmental Modelling and Software Society (iEMSs), 1-12.

FINKA M., KLUVÁNKOVÁ T. (2015), Managing complexity of urban systems: $A$ polycentric approach, Land Use Policy 42, 602-608.

FLOOD R. L. (2010), The Relationship of 'Systems Thinking' to Action Research, Systemic Practice and Action Research 23 (4), 269-284.

FOLKE C. (2006), Resilience: The emergence of a perspective for social-ecological system analyses, Global Environmental Change 16 (3), 253-267.

GALLOPIN G. C. (2006), Linkages between vulnerability, resilience, and adaptive capacity, Global Environmental Change 16, 293-303.

GARMESTANI A. S. (2014), Sustainability science: accounting for nonlinear dynamics in policy and social-ecological systems, Clean Technological Environmental Policy 16, 731-738.

GONZÁLEZ DE MOLINA M., TOLEDO V. M. (2014), The Social Metabolism: A Socio-Ecological Theory of Historical Change, Springer, London.

GUNDERSON L. H. (2000), Ecological resilience - in theory and application, Annual Review of Ecology and Systematics 31, 425-439.

HAJDUGA P. (2014), Special economic zones in the Lower Silesia region as a regional development stimulator during the crisis, Research Papers of Wrocław University of Economics $334,56-65$

HELLESLAND J. (2012), Evaluation of effective length formulas and applications in system instability analysis, Engineering Structures 45, 405-420.

HINSCH M., KOMDEUR J. (2010), Defence, intrusion and the evolutionary stability of territoriality, Journal of Theoretical Biology 266, 606-613.

HUMEAU J. B., PEPTENATU D., PINTILII R., DRĂGHICI C., SCHVAB A. (2010), The

Role of Polycentric Network in the Demographic Dynamic of Human Settlements, Journal of Urban and Regional Analysis 2 (1), 25-37.

IANOŞ I. (2000), Territorial systems. A geographical approach (In Romanian), Technical Publishing House, Bucharest.

IANOŞ I., PEPTENATU D., ZAMFIR D. (2009), Respect for environment and sustainable development, Carpathian Journal of Earth and Environmental Sciences 4 (1), 81-93.

IANOŞ I., PETRIŞOR A.-I., STOICA I. V., SÂRBU C. N., ZAMFIR D., CERCLEUX A.-L. (2011), The different consuming of primary eco-energies and their degradation in territorial systems, Carpathian Journal of Earth and Environmental Sciences 6 (2), 251-260.

KENC J. (2013), The effects of town twinning in the Lower Silesia voivodeship - a comparison of the situation in small, medium and large towns, Research Papers of Wrockaw University of Economics 282, 112-121.

KIEL L. D. (1991), Lessons from the Nonlinear Paradigm: Applications of the Theory of Dissipative Structures in the Social Sciences, Social Science Quarterly 72 (3), 431-442.

KRETSCHMANN J. (2013), Stakeholder orientated sustainable land management: The Ruhr Area as a role model for urban areas, International Journal of Mining Science and Technology 23, 659-663.

LAMBIN E. F., MEYFROIDT P. (2010), Land use transitions: Socio-ecological feedback versus socio-economic change, Land Use Policy 27, 108-118. 
Andrei SCHVAB, Igor SîRODOEV, Mirela PARASCHIV, Natașa VĂIDIANU (1), 1-28.

LANGER J. S. (1980), Instabilities and pattern formation, Revues of Modern Physics 52

MANSON S. M., O'SULLIVAN D. (2006), Complexity theory in the study of space and place, Environment and Planning A 38 (4), 677-692.

MARTIN R. (2010), Roepke lecture in economic geography - rethinking regional path dependence: beyond lock-in to evolution, Economic Geography 86 (1), 1-27.

MARTIN R., SUNLEY P. (2006), Path dependence and regional economic evolution, Journal of Economic Geography 6 (4), 395-437.

MARTIN R., SUNLEY P. (2010), The place of path dependence in an evolutionary perspective on the economic landscape, in: BOSCHMA R., MARTIN R., Handbook of evolutionary economic geography, Edward Elgar, Cheltenham, pp. 62-92.

MORANDI F., CAMPBELL D. E., BASTIANONI S. (2014), Set theory applied to uniquely define the inputs to territorial systems in emergy analyses, Ecological Modelling 271, 149-157. NUNES S., LOPES R. (2015), Firm Performance, Innovation Modes and Territorial Embeddedness, European Planning Studies 23 (9), 1796-1826.

OHLA C., KRAUZEB K., GRÜNBÜHEL C. (2007), Towards an understanding of longterm ecosystem dynamics by merging socio-economic and environmental research criteria for long-term socio-ecological research sites selection, Ecological Economics 63, 383-391.

OLSZAK C., ZIEMBA E. (2011), The determinants of knowledge based economy development - ICT use in the Silesian enterprises, Research Papers of Wrockaw University of Economics 206, 204-212. 87-115.

PAGE S. E. (2006), Path dependence, Quarterly Journal of Political Science 1 (1),

PIKE A., DAWLEY S., TOMANEY J. (2010), Resilience, adaptation and adaptability, Cambridge Journal of Regions, Economy and Society 3 (1), 59-70.

PINCETLA S., BUNJEB P., HOLMESC T. (2012), An expanded urban metabolism method: Toward a systems approach for assessing urban energy processes and causes, Landscape and Urban Planning 107, 193-202.

POPŁAWSKI M. (2013), Impact of foreign direct investment on Lower Silesia's economic development, Journal of Intercultural Management 5 (2), 31-62.

PRIGOGINE I. (1997), The end of certainty: time, chaos, and the new laws of nature, The Free Press, New York.

PRIGOGINE I., STENGERS I. (1984), Order Out of Chaos: Man's New Dialogue with Nature, Bantam Books, New York.

REUSCHKE D., SALZBRUNN M., SCHÖNHÄR K. (eds.) (2013), The economy of urban diversity: the Ruhr area and Istanbul, Palgrave Macmillan, New York.

RILEY R., TKOCZ M. (1999), Local responses to changed circumstances: Coalmining in the market economy in Upper Silesia, Poland, GeoJournal 48, 279-290.

SCHMIDT J. C. (2011), Challenged by instability and complexity..., in: Hooker C., Philosophy of Complex Systems, Elsevier, Amsterdam, pp. 223-254.

SIKULA N. R., MANCILLAS J. W., LINKOV I., MCDONAGH J. A. (2015), Risk management is not enough: a conceptual model for resilience and adaptation-based vulnerability assessments, Environment System Decision 35, 219-228.

STOKOLS D., PEREZ LEJANO R., HIPP J. (2013), Enhancing the resilience of humanenvironment systems: a social-ecological perspective, Ecology and Society 18 (1), 7.

ȘERBAN P.-R., TĂLÂNGĂ C. (2015), Is social resilience an economic structure issue or just the ability of communities to cope with external stress? Journal of Urban and Regional Analysis 7 (1), 59-68.

TÖDTLING F., SKOKAN K., HÖGLINGER C., RUMPEL P., GRILLITSCH M. (2011), Innovation and knowledge sourcing of modern sectors in old industrial regions: comparing software firms in Moravia-Silesia and Upper Austria, European Urban and Regional Studies 20 (2), 188-205.

VĂIDIANU N., PARASCHIV M., SAGHIN I., BRAGHINĂ C. (2015), Social-ecological consequences of planning and development policies in the Danube Delta Biosphere Reserve, 
Romania, Carpathian Journal of Earth and Environmental Sciences 10 (3), 113-124.

WALKER J., COOPER M. (2011), Genealogies of resilience: From systems ecology to the political economy of crisis adaptation, Security Dialogue 42 (2), 143-160.

WEGENER M. (2012), Government or Governance? The Challenge of Planning for Sustainability in the Ruhr, in: Hartmann T., Needham B. (eds.), Planning by Law and Property Rights Reconsidered, Surrey, Ashgate, pp. 157-168.

YOUNG O. R., BERKHOUT F., GALLOPIN G. C., JANSSEN M. A., OSTROM E., VAN DER LEEUW S. (2006), The globalization of socio-ecological systems: An agenda for scientific research, Global Environmental Change 16, 304-316.

ZHAO W. (2012), Analysis on the Characteristic of Energy Flow in Urban Ecological Economic System - A Case of Xiamen City, Procedia Environmental Sciences 13, 2274-2279.

ZURLINI G., RIITTERS K., ZACCARELLI N., PETROSILLO I., JONES K. B., ROSSI L. (2006), Disturbance patterns in a socio-ecological system at multiple scales, Ecological Complexity 3, 119-128.

ZUZAŃSKA ŻYŚKO E., SZAJNOWSKA WYSOCKA A. (2013), The Upper Silesian conurbation on the path towards the "Silesia" metropolis, Bulletin of Geography. Socioeconomic Series 21, 111-124.

Initial submission: 07.09.2015

Revised submission: 13.11 .2015

Final acceptance: 04.12.2015

Correspondence: Interdisciplinary Centre for Advanced Research on Territorial Dynamics (CICADIT), University of Bucharest, 4-12 Regina Elisabeta Blv., 030018, Sector 3, Bucharest, Romania.

E-mail: andrei.schvab@isb.ro 
